\title{
THE EFFECT OF MOTIVATION, THE ENVIRONMENT WORK AND THE LEADERSHIP PRINCIPAL'S ON TEACHER'S PERFORMANCE IN SMAN AMBULU
}

\author{
Haris Sutanto 1 \\ Mohammad Dimyati ${ }^{2}$ \\ Agustin HP $^{3}$ \\ Higher Education of Economic Mandala \\ e-mail: harissutanto008@gmail.com
}

\begin{abstract}
The effect of work motivation, environment work and principal leadership to the teacher performance in SMAN Ambulu. There are three problems in this research. They are 1) The work motivation effect partially to the teacher performance; 2) The work environment effect partially to the teacher performance; 3) The principal leadership affect partially to the teacher performance. The population used in this research were all of the teachers of SMAN Ambulu that consist of 56 teachers. The sum of sample needed in this research were 40 teachers. The data analysis method used experiment of doubled linier regression by using Microsoft Excel and SPSS program. The result of the research and data analysis shows that 1) the work motivation affect partially to the teacher's performance significantly. The significant value of statistical variable work motivation is 0,02 . So, its significant value is smaller than 0,05 or $0,002<0,05$. 2) work environment affect partially to the teacher performance significant. The significant value of statistical variable work environment 0,000 . So, its significant value is smaller than 0,05 or $0,000<0,05$. 3) The significant value of statistical variable of the principal leadership is 0,000 . So, its significant value is smaller than 0,05 or $0,000<0,05$. The conclusion is that work motivation, work environment and the principal's leadership can increase their performance significantly.
\end{abstract}

Keyword: work motivation, work environment, principal leadership, and teacher performance

\section{INTRODUCTION}

Competition in today's global era requires every country to prepare human resources to have high quality, intelligent, critical, creativity and able to face the increasing of several challenges. The education sector must respond to these challenges by improving the quality of the educational process continually in order to be able to deliver the students to achieve qualifications according to the demands of this era.Therefore, the teacher as a facilitator for the students should improve their performance in order to prepare the next generation of the nation.

According to Law number 14 of 2015 on teachers and lecturers in Chapter I Article 1 states that Teachers are professional educators with the main task of educating, teaching, guiding, directing, 
training, assessing, and evaluating learners in early childhood for formal education, Primary Education, and Secondary Education. While the position of teachers as professionals aims to implement the national education system and realize the goals of national education, namely the development of potential learners in order to become human beings who believe and pious to God Almighty, full of morality, healthy on physical and emotional, knowledgeable, capable, creative, independent, and able to become a democratic and responsible citizen. The professional duties of teachers according to article 2 of Law no. 14 of 2005 covers (1) conducting quality learning as well as assessing and evaluating learning outcomes, (2) enhancing academic qualifications and competencies in a sustainable manner with the development of science, and (3) upholding the law and teacher code of ethics and values - religious and ethical values and can nurture, foster unity and national unity.

A research by Sutikno (2015) concluded that the motivation of work has a significant effect on the performance of teachers of SMK Negeri 5 Jember. Djatmiko (2005: 67) stated that "Motivation of work is a process that encourages, directs and maintains human behavior towards the achievement of a goal". Another opinion which is in line with the above statement stated by Hasibuan (2007: 143) which states "Motivation of work is the provision of the driving force that creates a passionate work of a person so that they want to cooperate, work effectively, and integrated with all the effort to achieve satisfaction".

Arianto's research (2013) concluded that the work environment has a significant effect on the performance of faculty. According sedarmayati (2001: 1) work environment is the whole tooling tools and materials encountered, the environment around which a person works, methods of work, and arrangement of work both individuals and as a group. Working environment conditions are said to be good or appropriate if humans can carry out activities optimally, healthy, safe and comfortable.

A research by Pratiwi (2013) concluded that the leadership style of principals have a significant effect on the performance of SMP Negeri teachers in Wonogiri regency. It clarified by Sutarto (1998: 25) that definition of leadership is a series of activities in the form of the ability to effect the behavior of others is a certain situation in order to be willing to work together to achieve the goals set.

As a senior high school, SMAN Ambulu has a vision of "Superior through the balance of Moral, Intellectual, Cultural Arts with environmental insight". The mission is to (1) Increase the professionalism of service in ICT-based learning process, (2) Achieve excellence IMTAQ, Science and Culture, (3) Optimize curricular activities, (4) Improve the quality of religious deed amongs students. Therefore, to realize the vision of the mission, SMAN Ambulu undertakes various efforts such as (1) integration of vision and mission indicators into teaching and learning process conducted by teachers, (2) planned programs should lead to the achievement of school vision and mission indicators, (3) using local culture for self-development, (4) designing creative steps that can change student attitudes and behavior, (5) empowering extracurricular activities, (6) cooperating students in making learning projects, (7) optimizing principals' authority in supporting SBM, (8) optimizing all potentials in school, and (9) empowering teachers through MGMPS containers. All efforts to realize the vision of the mission above will be realized if the manager becomes a leader in the integration, emerges 
a beneficial working environment, and keep the good performance.

According to Sutikno (2015) teacher work motivation can be interpreted as an encouragement that exists both from within a teacher himself and from the surrounding which causes the teacher has a strong desire to work and fulfill his duties as a teacher in order to achieve the purpose of educating on his activities.

Therefore, the motivation of teacher work can be interpreted as an incentive or stimulus that exists either from within or outside the teacher self to create excitement of work and fulfill its duties as a teacher as a teacher and educator in order to achieve the goals or objectives of teaching and learning activities in school. According to Zainal Aqid (2004: 23) the teacher is an important element in the education process. In the process of education in schools, teachers hold multiple tasks: teachers and educators. As teacher, they are in charge of pouring a number of lesson material, into the brain of students, while as educators, they are in charge of guiding and fostering students to become capable, active, creative, and independent human.

Teacher motivation factor is a driving factor for a teacher for achievement that comes from within the person concerned that includes: (1) career goals, (2) working, (3) gaining experience, (4) experience. According to Supardi in Subroto (2005), work environment is the situation around the workplace which both physically and non physically can give a pleasant impression, secure, reassure, and feel at work. Nitisemeto (in Intanghina 2008) defines the work environment is everything that is around the workers who can effect himself in carrying out the tasks that are embedded. Meanwhile, Sedarmayati (in Intanghita 2008) states the work environment as the whole tooling tools and materials faced by the surrounding environment where a person works, the method works, and the arrangement of his work, either as an individual or as a group.

Work environment can be divided into 2 (two) types, namely social work environment and physical work environment. The social work environment includes working relationships within the institution. We are not alone in working at institutions, and in doing activities, we also need the help of others. Thus, we are obliged to maintain good relations between coworkers, subordinates and bosses because we need each other. Working relationships that are formed greatly affect the psychology of employees. Physical work environment is the workplace of employees doing their activities. The physical work environment affects employee's morale and emotion. These physical factors include the temperature of the air in the workplace, the area of work space, noise, density and distress.

Robbins (2002) states that factors affect the physical work environment are temperature, noise, lighting, and air quality. Temperature is a variable in which there are large individual differences. In order to maximize productivity, it is important that employees work in an environment where the temperature is set properly and in the range of acceptance by each individual. Evidence from noise studies suggests that constant or predictable voices generally do not cause workers' degradation performance, whereas the effects of unpredictable sounds negatively impact and interfere their concentration. Working in a dark and vague room will cause eye strain. The right light intensity can help employees in facilitating work activities.

The quality of air is a fact that can not be ignored that breathing contaminated air caused a detrimental effect on personal health. The polluted air can disrupt the health of employees. Air polluted in the 
work environment can cause headaches, sore eyes, fatigue, irritability and depression.

Another factor that affects the physical work environment is the design of the workspace. Work space greatly affects employee's performance. A narrow work space and poorly-performing employees will result in lower performance when compared to employees with large work spaces. If the work space refers to the size of the staff room, the setting refers to the distance between people and others. Working room arrangement is important because it greatly affects the social interaction. People mostly interact with physically close individuals. Therefore, the location of the employee's work affects the information that wanted to be known.

Rivai (2005: 2), in his book entitled "Leadership and Organizational Behavior", states that definition of leadership broadly, is covering the process of influencing in determining organizational goals, motivating follower behavior to achieve goals, influencing the interpretation of followers to the events, organizing the activities to achieve goals, maintaining cooperative relations and group work, obtaining support and cooperation from people outside groups or organizations. According to Hasibuan (2003: 170), leadership is the way a leader affects the subordinates' willingnes to work together and do an effective and efficient work to achieve organizational goals.

Furthermore, according to Istianto (2009: 87) in his book Management Government, there are several definitions of leadership that can represent about leadership as follows:

1. Leadership is an activity in the lead while the leader is the person who has the ability to affect others so they are following what he wants. Therefore leader must be able to organize and arrange others to achieve common goals.
2. Leadership is where a leader must be able to organize and affect others to achieve common goals.

3. Leadership is an important subject in management and administrative science because leadership is related to the relationship between superiors and subordinates within the organization.

4. Leadership is a process oriented to humans and can be measured from its effect on organizational behavior.

5. Government leadership is the attitude, behavior and activities of the leaders of the central and regional governments in an effort to achieve the goal of state administration.

According Sedarmayanti (2008), the meaning of leadership is as follows:

a. Leadership is activity of influencing people to strive willingly for mutual objectivesIn other words, leadership is the overall activity / activities to affect the ability of others to achieve the same purpose (George.R.Terry).

b. It can be said that leadership is the activity of the holder of authority and decision-making (Robert Dubin)

c. Leadership is the core of management for leadership is the driving force for human resources and other natural resources (Prof. Dr. S. P. Siagian)

d. It is in line with a statement that "Leadership is a process of influencing group activity in the effort of formulation and achievement of goals". (Ralph.M.Stogdill)

From the above explanation, it can be concluded that the definition of leadership is a way of a leader in his efforts to affect his subordinates to want to work together to achieve organizational goals.

The principal is an additional job or assignment of a teacher. The principal's position can be likened to a manager in a company or organization. According to Wahjosumidjo (2005: 83), the principal is a 
functional teacher who is given the task to lead a school where the learning process is held, or where there is an interaction between the teacher giving the lesson and the student receiving the lesson. Meanwhile, Mulyasa (2009: 24) states that principal is one component of education that plays an important role in improving the quality of education.

From the experts' opinion, it can be concluded that principal is a functional person who plays a role in improving the quality of education, besides the principal is also responsible for the implementation of education, school administration, educator training, supervisor at the school he leads and the maintenance of facilities and infrastructure.

Some of the principal's role in the new paradigm of education management (Mulyasa: 2009), are as follows:

a. The school principal as educator

b. Principal as manager

c. Principal as administrator

d. Principal as supervisor

e. Principal as leader

f. The school principal as innovator

In the implementation of the performance of teachers or educational personnel can be measured by using five aspects that can be used as measurement dimensions presented by Mitchell quoted Mulyasa (2009: 138), namely:

1. Quality of Work

2. Promtness (punctuality)

3. Initiative (initiative)

4. Capability (ability)

5. Communication (communication

Based on the Regulation of the Minister of National Education of the Republic of Indonesia No. 16 of 2007 regarding Academic Qualification Standard and Teacher Competency, it is explained that the academic qualification standard and teacher competence are fully developed from 4 main competencies, namely: 1) padagogic competence, 2) personality competence, 3) social competence and 4) professional competence.

According to the Regulation of the State Minister of Administrative Reform and Bureaucratic Reform No. 16 of 2009, the assessment of teacher performance is the assessment of each item of main task of the teacher in the framework of career development, rank, and position. Implementation of the main tasks of teachers can not be separated from the ability of a teacher in the mastery of knowledge, application of knowledge and skills, as required competencies as mandated by Minister of National Education Regulation No. 16 of 2007 on Academic Qualification Standards and Teacher Competencies.

Meanwhile, based on the Government Regulation of the Republic of Indonesia Number 46 Year 2011 on the Performance Appraisal of Civil Servants, Job Performance is the work achieved by every civil servant in the organization unit in accordance with the employment objectives and employee behavior. The elements assessed from employment goals and employee behavior are service orientation, integrity, commitment, discipline, cooperation and leadership.

Based on the description and phenomena that have been described above, then this study discusses the effect of work motivation, work environment, and leadership on teacher's performance in SMAN Ambulu.

\section{RESEARCH METHODS}

This type of research is causality research. The sampling technique in this research is done by using purposive sampling technique. By determining the sample criteria are (1) civil servant teachers and GTT (2) have served at least 5 years.The purpose of determining the 
criteria for the sample is more homogeneous. This study used a sample of about 40 people. Data collection techniques in this study were conducted by using questionnaires, interviews and literature study.

While the data analysis used is statistic and the purpose of this study is to test the hypothesisThe way used to measure respondents' answers is by using Likert scale for independentvariable of work motivation, work environment and leadership of principal while the dependent variable is teacher performance. Data analysis method used is descriptive analysis, validity test, reliability test, test of normality, linearity test, heteroscedasticity test, multiple linear analysis, partial test (t).

\section{RESULT ANALYSIS}

Table 5. Recapitulation of Results of Multiple Linear Regression Analysis

\begin{tabular}{|c|c|c|c|c|c|}
\hline \multirow[t]{2}{*}{ No. } & \multirow[t]{2}{*}{ Free Variable } & \multirow{2}{*}{$\begin{array}{l}\text { Regression } \\
\text { coefficient }\end{array}$} & \multicolumn{2}{|c|}{$\begin{array}{c}\text { Presentation of } \\
\text { hypotheses }\end{array}$} & \multirow[t]{2}{*}{ Sign. } \\
\hline & & & $t$-count & t-table & \\
\hline 1. & Motivation $\left(\mathrm{X}_{1}\right)$ & 0,231 & 2,119 & 2,028 & 0,041 \\
\hline 2. & $\begin{array}{l}\text { Work environment } \\
\left(\mathrm{X}_{2}\right)\end{array}$ & 0,432 & 3,153 & & 0,003 \\
\hline 3. & Leadhership $\left(\mathrm{X}_{3}\right)$ & 0,463 & 4,010 & & 0,000 \\
\hline \multicolumn{2}{|c|}{ Constants } & $=-0,112$ & & & \\
\hline \multicolumn{2}{|l|}{$\mathrm{R}^{2}$} & $=0,706$ & & & \\
\hline \multicolumn{2}{|l|}{ F-count } & $=28,755$ & & & \\
\hline \multicolumn{2}{|c|}{ F-table $_{(5 \% ; 3,36)}$} & $=2,866$ & & & \\
\hline \multicolumn{2}{|c|}{ Significance } & $=0,000$ & & & \\
\hline
\end{tabular}

Source: Appendix 10, data is processed

Based on the result of multiple linear regression analysis obtained regression equation is as follows:

$$
\mathrm{Y}=-0.112+0.231 \mathrm{X} 1+0.432+0.463 \mathrm{X}_{2} \mathrm{X}_{3}
$$

From the multiple linear regression equation above can be seen the effect of independent variables (motivation, work environment and principal's leadership) to the dependent variable (teacher's performance), while the meaning of multiple linear regression equation above can be explained as follows:

a. The constant regression equation $\left(b_{0}\right)$ is negative amounting to 0.112 , meaning that if there are no values of the independent variables or independent variables equal to zero, then the teacher's performance is negative. b. Motivation variable regression coefficient $\left(b_{1}\right)$ positive value of 0.231 , meaning that an increase in work motivation of teachers will be followed by an increase in the performance of teachers assuming the other independent variables constant.

c. Work environment variable regression coefficient $\left(b_{2}\right)$ positive value of 0.432 , meaning that an increase in the working environment will be followed by an increase in the performance of teachers assuming the other independent variables constant. 
d. Variable regression coefficient school leadership (b 3) positive value of 0.463 , meaning that an increase in school leadership will be followed by an increase in the performance of teachers assuming the other independent variables constant.

Table 6. Recapitulation of Test Results $t$

\begin{tabular}{|l|c|c|c|}
\hline \multicolumn{1}{|c|}{ Variabel } & t-hitung & t-tabel & Sig. \\
\hline Motivation $\left(\mathrm{X}_{1}\right)$ & 2,119 & 2,028 & 0,041 \\
\hline Work environment $\left(\mathrm{X}_{2}\right)$ & 3,153 & 2,028 & 0,003 \\
\hline Leadhership $\left(\mathrm{X}_{3}\right)$ & 4,010 & 2,028 & 0,000 \\
\hline
\end{tabular}

Source: Appendix 10, data is processed

Based on the $t$ test steps and the above table, the hypothesis testing for each independent variable of motivation, work environment and principal's leadership on performance are as follows:

1. Motivation variable $\left(\mathrm{X}_{1}\right)$

Based on the above table, it is known that t-count value of motivation variable is 2,119 with probability value equal to 0,041 , while $t$-table value is 2,028 (Appendix 13), so t-count>t-table (2,119> $2,028)$. It shows that the variable of motivation partially have a significant effect on teacher performance.

2. Work environment variables $\left(\mathrm{X}_{2}\right)$

Based on the above table, it is known that the t-count value of work environment variables is 3.153 with probability value of 0.003 , while the $t$-table value is 2.028 , so that $\mathrm{t}$-count $>\mathrm{t}$-table $(3.153>2.028)$. It shows that the working environment variables partially have a significant effect on teacher performance.

3. Leadership principals variable $\left(\mathrm{X}_{3}\right)$

Based on the above table, it is known that the t-count value of principal leadership variables is 4.010 with probability value of 0.000 , while the $\mathrm{t}$ table value is 2.028 , so t-count $>\mathrm{t}$-table (4.010> 2.028). It shows that the principal leadership variable partially has a significant effect on teacher performance.

\section{INTERPRETATION}

\section{Effect of Work Motivation on Teacher Performance}

This research indicates that the motivation of work significantly affect the performance of teachers in SMAN Ambulu. It can be seen from the significance of 0.02 . The Research conducted shows that teachers in carrying out their duties require work motivation. Work motivation on career target indicator shows that the teacher in performing his duty is motivated by the spirit to gain promotion and obtain certain position / additional task such as vice principal, homeroom, extra coach etc. This evidence is shown in Table 4.7, from 40 respondents it is found that $20 \%$ answered neutral, 20\% answered agree and 60\% answered strongly agree. It shows the majority of respondents say agree if the teacher will be eager in carrying out the task because they have the desire to get promotion.

Motivation of work on the work indicator, said that teachers who have high motivation to work because they have the desire to create new learning method and produce papers. Information in Table 4.7 shows that from 40 respondents known $20 \%$ answered neutral, 20\% answered 
agree, and $60 \%$ answered strongly agree. It indicates the majority of respondents strongly agree if the teacher will have high teaching motivation because they want to get a new learning method is good and suitable for learners. While $22.5 \%$ answered neutrally, 8 percent answered agree, and $57.5 \%$ answered strongly agree It signifies the majority of respondents strongly agree if teachers teach with high motivation will produce good writing. Such circumstances are supported by the desire of teachers who will be promoted must enclose scientific papers as one of the conditions in proposing promotion.

Work motivation on the indicators gained experience states that teachers in conducting the teaching and learning process are considered to gain additional knowledge of science and can recognize the characteristics of different students. Motivation of work on indicators of worship states that teachers in implementing their duties as teachers and educators are based on the belief that teaching and educating is a deed of worship to God Almighty. It can be known in Table 4.7, from 40 respondents, $30 \%$ answered agree and $70 \%$ answered strongly agree. This shows that the majority of respondents strongly agree that teaching and educating students well is a deed of worship.

The results of this study are in accordance with Handayani research findings, and Rashid (2015), Fitrah (2014), Eros (2014), Dewi (2012), Bahri (2011), where the motivation of work partially significant effect on teacher performance in SMAN Ambulu.

\section{The Effect of the Working Environment Performance Against Teachers}

This study shows that the work environment has an effect on the performance of teachers in SMAN Ambulu. It can be seen from the significance of 0.000 . The Research shows that a good work environment will support the performance of teachers in their daily life. The work environment on hygiene indicators shows that a clean working environment will make a comfortable working condition, create an attractive workplace and healthy body. The assessment of respondents to the statement: clean environment makes comfortable work (table 4.8), it shows that from 40 respondents, $20 \%$ answered agree and $80 \%$ answered strongly agree. From the statement of the clean environment can create an attractive workplace, it is known that $32 \%$ respondents answered agree and $68 \%$ others answered strongly agree. From the statement of the clean environment creates healthy body, it is obtained that $40 \%$ respondents answered agreed and the rest $60 \%$ answered strongly agree. It shows the majority of respondents strongly agree if a clean working environment makes comfortable in work, create an attractive workplace and healthy body. To realize a clean environment, schools are required to dispose of garbage on the place properly and clean up the teachers' room and classroom every day by school officials and student pickets.

The work environment on the coloring indicator indicating that the color of a good work space will foster morale and create new inspiration so that the performance of teachers will be better. Assessment of respondents to the statement that a good color will grow morale shown in Table 4.8 of 40 respondents. It is known that $17.5 \%$ answered neutral, $45 \%$ answered agree, and $37.5 \%$ answered strongly agree. While the respondent's assessment of the statement that suitable colors inspire resulted in $22.5 \%$ answered neutral, $45 \%$ answered agree and $32.5 \%$ answered strongly agree. It shows that the majority of respondents agreed that the work 
environment with a good and suitable color will foster morale and inspire. To fulfill that term, there is a regular painting activity on teachers room, staffs room and classroom periodically which is once a year.

The work environment on the air circulation indicator states that work environment which has a good air circulation will cause the air in the work space becomes not hot and feels fresh. The respondents' assessment of the statement is shown in Table 4.8 that from 40 respondents, $2.5 \%$ answered disagree, $2.5 \%$ answered neutral, $47.5 \%$ answered agree, and $47.5 \%$ answered strongly agree. While the respondents evaluation of the statement of air circulation in the class create the learning process run smoothly, $10 \%$ answered neutral, $40 \%$ answered agree and the rest $50 \%$ answered strongly agree. It indicates that the majority of respondents said strongly agree that the work environment has a smooth air circulation that creates a room that is not hot and fresh air so that teachers who are in the room will feel comfort in performing their duties. To support that circumstance, the school creates a room that has many ventilations and accompanied by planting trees that are useful as a source of oxygen producers.

In the indicator of relationships among teachers said that a good work environment can be shown by good interteacher relationships with indications of communication among teachers smooth and between teachers of subjects in their discussion. Assessment of respondents to the statement shown in Table 4.8, from 40 respondents found that $2.5 \%$ answered neutral, 20\% answered agree and $77.5 \%$ answered strongly agree.

While the next result shows that $35 \%$ answered agree and 65\% answered strongly agree. It shows that the majority of respondents strongly agree that the relationship between teachers are harmonious shown by smooth communication will affect on better teacher performance. To support this term, the school held a school teacher meeting (MGMPS) gatherings every week and visitation event every 2 months.

The results of this study are in accordance with the research findings of Arianto (2013), Sofyan (2013), Firmansyah (2008), where the work environment partially significant effect on teacher performance in SMAN Ambulu.

\subsubsection{The Effect on Teacher's Performance Principalis Leadership}

This study shows that the principal's leadership affects the performance of teachers in SMAN Ambulu. This can be seen from the significance of 0.000 . The Research conducted shows that the leadership of the principal-oriented tasks and task-oriented at the subordinate will cause teachers to be spirit in carrying out their duties. The principal's leadership on the task-oriented indicator of task completion says that the principal must have timeliness in completing the work. Assessment of respondents to the statement is shown in Table 4.9, from 40 respondents, $2.5 \%$ answered neutral, 50\% answered, and $47.5 \%$ answered strongly agree. While other statements say the principal is able to complete the assigned tasks obtained results, $57.5 \%$ answered agree and $42.5 \%$ answered strongly agree. It indicates that the majority of respondents agree that the principal must have timeliness in completing the work and be able to perform their duties properly.

The principal's leadership on the subordinate-oriented indicator says the principal can select reliable subordinates in his work and can work together on a team basis. Assessment of respondents statement shown in Table 4.9, from 40 
respondents, $10 \%$ answered neutral, $45 \%$ answered agree, and $45 \%$ answered strongly agree. While in the next statement obtained 5\% answered neutral, $40 \%$ answered agree and 55\% answered strongly agree. It explains that majority of respondents strongly agree if the principal should be able to select subordinates who can work well and can work together teamwork in completing the task. This situation is realized in school with the principal at the time of choosing subordinates, such as vice principals, members of the development team with a selection and regeneration system. In the statement that the principal provide for subordinates freedom of opinion, from the 40 respondents, 5\% answered neutral, $45 \%$ answered agree, and 50\% answered strongly disagree. Whereas in a statement that the principal provide guidance, direction and encouragement to his subordinates, $40 \%$ answered agree, and $60 \%$ answered strongly disagree. It indicates that majority of respondents strongly agreed that the principal must provide freedom of opinion and provide guidance to subordinates. This condition is manifested in the form habits of school principals who always invites deliberation to all his subordinates in the form of official meetings. Besides, principal also provides guidance to all teachers on a regular basis every Monday after fulfilling their flag ceremony.

The results are consistent with research findings Baihaqi (2015), Literacy (2015), Soetopo (2016), where the principal's leadership is partially significant effect on the performance of teachers at SMAN Ambulu.

\section{CONCLUSIONS}

Based on the analysis that has been done in this study, it can be concluded that:
1. Work motivation has a significant effect on the performance of teachers in SMAN Ambulu. The use of positive values of the test results show increase motivation to work while the teacher's performance will also increase. These results are the first to accept the hypothesis $\left(\mathrm{H}_{1}\right)$ which states that work motivation significantly the performance of teachers in SMAN Ambulu.

2. Work environment significantly affects to the performance of teachers in SMAN Ambulu. The use of positive values of the test results show that if the working environment is good, the teacher's performance also will be good. These results are appropriate with the second hypothesis $\left(\mathrm{H}_{2}\right)$ which states that the working environment significantly affect the performance of teachers in SMAN Ambulu.

3. School leadership has a significant effect on the performance of teachers in SMAN Ambulu. The use of positive values from the test results show if the principal leadership is good, teacher performance also will be good. These results are suitable to a third hypothesis $\left(\mathrm{H}_{3}\right)$ which states the principal's leadership significantly affects the performance of teachers in SMAN Ambulu.

\section{REFERENCES}

Arikunto.(2006). Metode Penelitian Ilmiah. Bandung : Rajawali

Arianto.(2013). Pengaruh Lingkungan Kerja Terhadap KinerjaGuru Honorer(Studi Kasus Guru Honorer SMANRumpun IPA Se-Kecamatan Ranuyoso).

Baihaqi ,Muhammad Iqbal .2015. Pengaruh Gaya Kepemimpinan Kepala Sekolah Dan Motivasi Kerja Terhadap Kinerja Guru Di Ma A'arif Selorejo Blitar. Jurnal KONSTRUKTIVISME, Vol. 7, 
No. 2, Juli 2015: FKIP Universitas IslamBalitar,Blitar

Cici Asterya Dewi (2012) Pengaruh Motivasi Kerja Terhadap KinerjaGuru Honorer(Studi Kasus Guru Honorer SMANRumpun IPS Se-Kecamatan Temanggung). Skripsi. Universitas Negeri Semarang.

Dimyati, Mohamad.2009. Analisis SEM dakam Uji Pengaruh Beberapa Variabel Terhadap Loyalitas, Kajian Berbasis Riset pada Debitur Kredit Usaha Kecil. Jakarta: Mitra Wacana Media.

Depdiknas. (2001). Manajemen Peningkatan Mutu Berbasis Sekolah; Buku 1 Konsep dan Pelaksanaan. Jakarta : Direktorat SLTP Dirjen Dikdasmen

Depdikbud. (2012). Buku Pedoman Pelaksanaan Penilaian Kinerja Guru. Jakarta.

Djatmiko. (2005). Menumbuhkan Motivasi Kerja Karyawan. Surabaya : PT Indo karya

Endy Eros Pengaruh (2014)Motivasi Dan Kedisiplinan Kerja Guru Terhadap Kinerja Guru Di SMPNegeri Kecamatan Brebes Kabupaten Brebes Jawa Tengah. Jurnal Administrasi Publik dan Birokrasi Vol. 1 No. 1, 2014, artikel 2.

Ferdinan .(2006). Metode Penelitian Ilmiah. Bandung : Rajawali

Fitrah, Moch Rizki. (2014). Pengaruh Disiplin Kerja dan Motivasi Kerja terhadap Kinerja Karyawan pada Hotel Bintang Mulia \& Resto Jember. Skripsi.Tidak Diterbitkan. Jember: Universitas Jember

Firmasyah. (2008). Pengaruh lingkungan Kerja Terhadap KinerjaGuru Honorer(Studi Kasus Guru Honorer SMANRumpun IPS Se-Kecamatan Punung).
Ghozali.(2005). Metode Penelitian Kuantitatif Dan Kualitatif. Bandung : PT Refika Aditama

Hasibuan, Malayu SP. 2008. Manajemen Sumber Daya Manusia. Jakarta: PT. Bumi Aksara

Hasibuan, Malayu S.P. 2005. Manajemen Prestasi Kerja. Jakarta: Rajawali

Istianto. (2008). Manajemen pemerintahan. Jakarta : PT Bumi Aksara

Kuncoro. 2007. Model Penelitian Kuantitatif dan Kualitatif. Bandung. PT Remaja Rosdajarya

Mulyasa. 2007. Kinerja Guru. Bandung. PT Remaja Rosdakarya

Mulyasa. 2009. Menjadi Kepala Sekolah Profesional. Bandung. PT Remaja Rosdakarya

Nisfiannorr, Mohammad. (2009) Model Penelitian Kuantitatif dan Kualitatif. Jakarta : PT Bumi Aksara

Nitisemeto. (2008).Kesehatan dan Keselamatan Lingkungan Kerja. Jakarta : Kencana Prenada Media Group

Mulyasa. 2009. Menjadi Kepala Sekolah Profesional. Bandung. PT Remaja Rosdakarya

Pratiwi. 2013. Pengaruh gaya kepemimpinan kepala sekolah terhadap kinerja guru SMP Negeri di Kabupaten Wonogiri. Wonogiri

Robbins (2002).Lingkungan dan Keselamatan Kerja. Bandung : Alfabeta

Rivai. (2005). Kepemimpinan dan perilaku Organisasi. Jakarta : PT Bumi Aksara

Sugiono. (2008). Metode Penelitian Kuantitatif, Kualitatif, fan $R \& D$. Bandung: Alfabeta.

Subroto.(2008). Lingkungan Kerja Sekolah. Jakarta. PT Renika Cipta

Sadar. 2015. Hubungan Persepsi Gaya Kepemimpinan Kepala Sekolah Dan Efikasi Diri Dengan Kinerja Guru.Tesis program magister psikologi 
sekolah pascasarjana : Universitas muhammadiyah Surakarta

Sutarto. (1998). Kepemimpinan dan Strategi. Jakarta : PT Renika Cipta

Sedarmayanti,2008. Manajemen Sumber Daya Manusia, Reformasi Birokrasi dan Manajemen PNS. Bandung: PT. Refika Aditama.

Siagian,P.Sondang.2007.. Mnajemen

Sumber Daya Manusia. Cetakan ke 15.Jakarta: PT.Bumi Aksara

Sugiyono. 2012. Metode Penelitian Bisnis. Bandung:Alfabeta

Suparno. 2007. Pengaruh Motivasi Kerja Dan Kepemimpinan Situasional Kepala Sekolah Terhadap Kinerja Guru SMPNegeri Di Kecamatan PemalangKabupaten Pemalang. Tesis. Universitas Negeri Semarang

Surya. 2004. Kinerja Guru. Bandung. Alfabeta

Sutikno. 2015. Pengaruh Gaya Kepemimpinan, Motivasi Kerja dan Kompensasi Terhadap Kinerja Guru Melalui Kepuasan Kerja. Tesis. STIE Mandala Jember.

Sofyan.(2013). Pengaruh Lingkungan Kerja Terhadap KinerjaGuru (Studi Kasus Guru SMAN Se-Kecamatan Boyolali).

Soetopo, Meita Pragiwani. 2016. Pengaruh kepemimpinan, pendidikan dan pelatihan Motivasi kerja, dan budaya organisasi Terhadap kompetensi dan kinerja guru. Jurnal STEI Ekonomi Volume 25 - Nomor 1, Juni 2016. Sekolah Tinggi Ilmu Ekonomi Indonesia

Syamsul Bahri (2011). Faktor Yang Mempengaruhi Kinerja Guru SDDi Dataran Tinggimoncong Kabupaten GowaProvinsi Sulawesi Selatan.Fakultas Teknik Universitas Negeri Makassar.

Titik Handayani, Aliyah A. RasyidPengaruh Kepemimpinan Kepala Sekolah,
Motivasi Guru, DanBudaya Organisasi Terhadap Kinerja Guru Sma Negeri Wonosobo. Universitas Negeri Yogyakarta

Uno. B. Hamzah. 2006. Teori Motivasi dan Pengukurannya.Jakarta: Bumi Aksara

Usman M. Uzer. 2005. Menjadi Guru Profesional. Bandung. Remaja Rosdakarya Vroom. 2006. Menumbuhkan Motivasi Kerja Karyawan. Jakarta : PT Rineka Cipta

Wahjosumidjo. 2005. Kepemimpinan Kepala Sekolah. Jakarta : PT Raja Grafindo. Persada

Zainal Aqib. 2002. Profesionalisme Guru dalam Pembelajaran. Surabaya: Cendekia. 